\title{
Polymorphisms in the Leptin and SCD genes in Buffaloes of the Amazon
}

\author{
Polimorfismos nos genes Leptina e SCD em Búfalas da Amazônia \\ Polimorfismos en los genes de Leptina y $S C D$ en Búfalas del Amazonas
}

Received: 09/29/2021 | Reviewed: 10/04/2021 | Accept: 10/07/2021| Published: 10/10/2021

Caio Santos Silva

ORCID: https://orcid.org/0000-0002-7904-5441 Federal University of Pará, Brazil

E-mail: scaio@hotmail.com

Ednaldo da Silva Filho

ORCID: https://orcid.org/0000-0002-8009-3504 Federal Rural University of the Amazon, Brazil

E-mail: tuca13@yahoo.com

Lorena Keyse Nery da Silva

ORCID: https://orcid.org/0000-0002-4883-1845

Federal Rural University of the Amazon, Brazil

E-mail: lorenakeyse24@gmail.com

Rafaella Sousa Ferraz

ORCID: https://orcid.org/0000-0002-0011-330X

Federal University of Pará, Brazil

E-mail: rafaellaferraz.16@hotmail.com

Amanda de Sousa Matos

ORCID: https://orcid.org/0000-0002-5639-4067

Federal University of Pará, Brazil

E-mail: amanda_smatos@hotmail.com

Larissa Coelho Marques

ORCID: https://orcid.org/0000-0003-1037-8835

University of Amazon, Brazil

E-mail: laracoel@gmail.com

Rodrigo Lima Sales

ORCID: https://orcid.org/0000-0001-9197-4772

Embrapa Eastern Amazon, Brazil

E-mail: laracoel@gmail.com

Diva Anelie de Araújo Guimarães ORCID: https://orcid.org/0000-0001-6638-8907

Federal University of Pará, Brazil E-mail: diva@ufpa.br

José Ribamar Felipe Marques

ORCID: https://orcid.org/0000-0002-9986-4719

Embrapa Eastern Amazon, Brazil E-mail:diva@ufpa.br

\begin{abstract}
The objective this work was to evaluate genetically the buffaloes populations using polymerase chain reactionrestriction fragment length polymorphism (PCR-RFLP) in the leptin and stearoyl-CoA desaturase (SCD) genes, and associate the genotypes with milk production. Sixty-nine samples of Bubalus bubalis - 38 Murrah breed, 18 Mediterranean and 13 mixed-breed of the Murrah with Mediterranean - were evaluated. Allele and genotype frequencies, the heterozygosity observed and expected, the inbreeding coefficients (FIS), the probabilities of the Hardy-Weinberg equilibrium, the F statistic for population differentiation and Shannon index were calculated using GENEPOP and GenALEx programs. The associations of the different genotypes with a role in milk production were tested by Analysis of Variance (ANOVA) and t-test. We reported the leptin and SCD allele contribution to genetic variability in buffaloes herds in the Brazilian Amazonian region. The A allele was more representative in leptin and SCD genes for all breed groups. No significant effects between genotypes and milk production were found in the present study, but there is an indicative that AA genotype in leptin gene affects milk production in Murrah breed.
\end{abstract}

Keywords: Bubalus bubalis; Genotype; Milk; SNP. 


\begin{abstract}
Resumo
O objetivo deste trabalho foi avaliar geneticamente as populações de búfalas por meio da reação em cadeia da polimerase e do polimorfismo no comprimento do fragmento de restrição (PCR-RFLP) nos genes da leptina e estearoil-CoA dessaturase (SCD), e associar os genótipos à produção de leite. Foram avaliadas 69 amostras de Bubalus bubalis - 38 da raça Murrah, 18 mediterrâneo e 13 mestiças da raça Murrah com Mediterrâneo. As frequências de alelos e genótipos, a heterozigosidade observada e esperada, os coeficientes de endogamia (FIS), as probabilidades de equilíbrio de Hardy-Weinberg, a estatística F para diferenciação populacional e o índice de Shannon foram calculados usando os programas GENEPOP e GenALEx. As associações dos diferentes genótipos com o papel na produção de leite foram testadas por Análise de Variância (ANOVA) e teste t. Nós relatamos a contribuição da leptina e do alelo SCD para a variabilidade genética em rebanhos bubalinos na região amazônica brasileira. O alelo A foi o mais representativo nos genes da leptina e SCD para todos os grupos raciais. Nenhum efeito significativo entre os genótipos e a produção de leite foi encontrado no presente estudo, mas há um indicativo de que o genótipo AA no gene da leptina afeta a produção de leite na raça Murrah.
\end{abstract}

Palavras-chave: Bubalus bubalis; Genótipo; Leite; SNP.

\title{
Resumen
}

Resumen - El objetivo de este trabajo fue evaluar genéticamente las poblaciones de búfalos mediante la reacción en cadena de polimerasa-polimorfismos de longitud de fragmentos de restricción (PCR-RFLP) en los genes de leptina y estearoil-CoA desaturasa (SCD), y asociar los genotipos con la producción de leche. Se evaluaron 69 muestras de Bubalus bubalis, 38 de la raza Murrah, 18 de la raza mediterránea y 13 mestizas de la raza Murrah con la mediterránea. Las frecuencias de alelos y genotipos, la heterocigosidad observada y esperada, los coeficientes de consanguinidad (FIS), las probabilidades del equilibrio de Hardy-Weinberg, el estadístico F para la diferenciación poblacional y el índice de Shannon se calcularon utilizando los programas GENEPOP y GenALEx. Las asociaciones de los diferentes genotipos con un papel en la producción de leche se probaron mediante Análisis de Varianza (ANOVA) y prueba $\mathrm{t}$. Reportamos la contribución de la leptina y el alelo SCD a la variabilidad genética en rebaños de búfalos en la región amazónica brasileña. El alelo A fue más representativo en los genes de leptina y SCD para todos los grupos de razas. En el presente estudio no se encontraron efectos significativos entre los genotipos y la producción de leche, pero hay indicios de que el genotipo AA en el gen de la leptina afecta la producción de leche en la raza Murrah.

Palabras clave: Bubalus bubalis; Genotipo; Leche; SNP.

\section{Introduction}

The total demand for animal food products is expected by FAO to more than double by 2030, driven by the growing middle-class population in developing countries (Briunsma, 2003). In Brazil, water buffalo (Bubalus bubalis) rearing has been developed on a large scale, with an annual increase of 1.1\% (IBGE, 2019).

Production and marketing of buffalo milk and their dairy products are well differentiated and have grown increasingly to attract consumers seeking nutritional and functional quality (Araújo et al., 2012). After dairy cows, water buffaloes are the second most important species in the world in terms of milk production (Safari et al., 2018). The components of buffalo milk, such as fats and total solids, make a higher quality than cow milk (Rosales \& Batalha, 2013). The mechanisms that regulate milk synthesis are controlled by several genes that can be considered as candidates for genetic variation in economically important traits in livestock selection strategies. Additionally, it would be useful to identify polymorphisms in these candidate genes, including those associated with quantitative trait for marker-assisted selection, used single nucleotide polymorphism (SNP), which can be applied in breeding programs in order to increase milk production (Naserkheil et al., 2019).

Among the various genes studied with reference to the production of milk in domestic animals leptin gene and stearoyl-CoA desaturase gene (SCD) were highlighted. The leptin gene is locally formed by the mammary gland (Bartha et al., 2005) and seems to have essential roles in gland growth (Hu et al. 2002) and lactogenesis (Feuermann et al., 2009). Whereas SCD gene is involved in the endogenous production of the cis-9, trans-11 isomers of CLA, which are generally found in ruminant milk and considered healthy in the human diet (Bhattacharya et al., 2006). 
Therefore, the objective of this study was to identify polymorphisms in leptin gene and $S C D$ gene, and associate polymorphisms with the production of milk in Murrah, Mediterranean and mixed-breed herds in the Brazilian Amazonian region.

\section{Methodology}

\section{Experimental Animals}

A total of 69 samples of B. bubalis, 38 of them being Murrah breed, 18 Mediterranean and 13 mixed-breed of the Murrah with Mediterranean were analyzed. The study complied with the Code of Ethics Protocol 002/2016 (Ethics Committee on Animal Use) and 22.1306023.00.00.

\section{Phenotypes used}

The total milk production was analyzed in each milking session within a 36 months period.

\section{Laboratory procedures}

A total of $5 \mathrm{~mL}$ of blood was collected from each animal and preserved in EDTA at $4^{\circ} \mathrm{C}$ to be analyzed in the laboratory.

Genomic DNA was extracted according to the protocol developed by Sambrook et al., (1989). Subsequently, the DNAs was quantified in $1.0 \%$ agarose gel and compared with increasing concentrations of DNA bacteriophage (50, 100 and 200ng/ $\mu \mathrm{L}$ ). The purity of DNA was evaluated in the Biomate 3 spectrophotometer (Thermoscientific, USA) within the range A260nm/A280nm and samples with rates equal to or higher than 1.8 were selected.

The polymerase chain reactions (PCR) were conducted in a final volume of $20 \mu \mathrm{L}$. The table 1 showed the primers used in the studied.

Table 1. Primers and length of each amplified fragment and anneal temperature.

\begin{tabular}{clcc}
\hline $\begin{array}{c}\text { Gene } \\
\text { fragment }\end{array}$ & \multicolumn{1}{c}{ Primer sequence } & $\begin{array}{c}\text { Anneal } \\
\text { temperature }\left({ }^{\circ} \mathrm{C}\right)\end{array}$ & $\begin{array}{c}\text { Length of gene } \\
\text { fragment }(\mathrm{bp})\end{array}$ \\
\hline \multirow{2}{*}{ LEPTIN } & F: 5'-GTCTGGAGGCAAAGGGCAGAGT-3' & 60 & 522 \\
& R: 5'-CCACCACCTCTGTGGAGTAG-3' & & 752 \\
SCD & F: 5'-GAAACTTCCCCAGTGCC-3' & 61 & \\
\hline
\end{tabular}

Source: Authors.

The reactions contained 1X of Buffer 10X, 2mM de $\mathrm{MgCl} 2,1 \mathrm{mM}$ of each dNTP, 2.5\% of Bovine Serum Albumin (Invitrogen, Brazil), $10 \mathrm{nM}$ of each primer (forward and reverse), 1U Taq DNA polymerase (Promega-Brazil) and $25 \mathrm{ng}$ genomic DNA. The reactions were performed using a Veriti Termal Cycle (Apllied Biosystem-USA) with an initial denaturation temperature of $95{ }^{\circ} \mathrm{C}$ for $5 \mathrm{~min}$ followed by 35 cycles with a denaturing temperature of $94{ }^{\circ} \mathrm{C}$ for $45 \mathrm{~s}$, respective annealing temperature for $61{ }^{\circ} \mathrm{C}$ for $1 \mathrm{~min}$, an extension temperature of $72{ }^{\circ} \mathrm{C}$ for $2 \mathrm{~min}$, followed by a final extension temperature of $72^{\circ} \mathrm{C}$ for $5 \mathrm{~min}$.

Polymorphisms in the Leptin and SCD genes, were detected by the RFLP technique using $03 \mu \mathrm{L}$ of PCR products, mixed with $0.5 \mu \mathrm{L}$ of BsaAI and TaqI respectively, restriction enzyme (New England Biolabs, Inc.), $0.1 \mu \mathrm{L}$ of reaction buffer 
and adjusted with ultrapure water to a volume of $15 \mu$ l. Subsequently heated to $37^{\circ} \mathrm{C}$ for $1 \mathrm{~h}$ for the leptin gene and $65^{\circ} \mathrm{C}$ for 5 $\mathrm{h}$ for the SCD gene. They were then visualized on Gelred stained 1.5\% agarose gel (Biotium / USA) and further visualized in transilluminator under ultraviolet light.

\section{Statistical analysis}

The program GENEPOP (Raymond \& Rousset, 1995) was used to determine the haplotype and genotype frequencies, the heterozygosity observed and expected, the inbreeding coefficients (FIS), the probabilities of the HardyWeinberg equilibrium and the estimates of the F statistic for population differentiation. The program GenALEx (Peakall \& Smouse, 2012) was used to calculate the Shannon index. The associations of the different genotypes with milk production were tested via Analysis of Variance (ANOVA) and t-test using R software https://www.r-project.org/ and visualized with 'ggpubr' package (Kassambara, 2020). The level of significance established was 0.05 .

\section{Results and Discussion}

For Leptin gene the PCR product were 522-bp covering intron 2 and exon 3. The A/G SNP was allocated in intron 2 and then genotyped by PCR-RFLP. Two different genotypes were detected as a result of the digestion of 522-bp fragment with BsaAI restriction enzyme and the genotypes designated as AA (522 bp), AG (522 and 439 bp). For SCD gene the PCR product were $752 \mathrm{pb}$ covering promoter region and exon 1 and then genotyped by PCR-RFLP. The transvertion g.133A >C creates a restriction site for the endonuclease TaqI and three digestion patterns were obtained and the genotypes designated as AA (752 bp), AC (752 and 620 bp) and CC (620 bp).

The number of genotypes, allele, expected $\left(\mathrm{H}_{\mathrm{e}}\right)$ and observed $\left(\mathrm{H}_{\mathrm{o}}\right)$, heterozygosity and shannon index (SI), inbreeding coefficient (Fis) and Hardy-Weinberg probability (HWP) are present in table 2 for all genes.

Table 2. Genotypic, allelic, and genetic characteristics of the populations

\begin{tabular}{|c|c|c|c|c|c|c|c|c|}
\hline Gene & Breed & Genotypes & Allele & $\mathrm{H}_{\mathrm{o}}$ & $\mathrm{H}_{\mathrm{e}}$ & SI & Fis & HWP \\
\hline & $\mathrm{MU}$ & AA (0.68) & $\mathrm{A}(0.84)$ & 0.32 & 0.27 & 0.44 & -0.17 & 0.34 \\
\hline & & $\mathrm{AG}(0.32)$ & $\mathrm{G}(0.16)$ & & & & & \\
\hline \multirow[t]{6}{*}{ Leptin } & $\mathrm{ME}$ & AA $(0.66)$ & $\mathrm{A}(0.83)$ & 0.34 & 0.28 & 0.46 & -0.19 & 0.24 \\
\hline & & $\mathrm{AG}(0.34)$ & $\mathrm{G}(0.17)$ & & & & & \\
\hline & MD & $\mathrm{AA}(0.31)$ & $\mathrm{A}(0.65)$ & 0.69 & 0.45 & 0.64 & -0.50 & 0.06 \\
\hline & & $\mathrm{AG}(0.69)$ & $\mathrm{G}(0.35)$ & & & & & \\
\hline & MU & AA $(0.83)$ & $\mathrm{A}(0.92)$ & 0,17 & 0,15 & 0,28 & $-0,09$ & 0,66 \\
\hline & & $\mathrm{AC}(0.17)$ & $\mathrm{C}(0.08)$ & & & & & \\
\hline \multirow[t]{5}{*}{$S C D$} & $\mathrm{ME}$ & $\mathrm{AA}(0.37)$ & $\mathrm{A}(0.63)$ & 0,50 & 0,47 & 0,66 & $-0,07$ & 0,71 \\
\hline & & $\mathrm{AC}(0.50)$ & $\mathrm{C}(0.37)$ & & & & & \\
\hline & & $\mathrm{CC}(0,13)$ & & & & & & \\
\hline & MD & AA (0.69) & $\mathrm{A}(0.85)$ & 0,50 & 0,26 & 0,43 & $-0,18$ & 0,51 \\
\hline & & $\mathrm{AC}(0.31)$ & $\mathrm{C}(0.15)$ & & & & & \\
\hline
\end{tabular}

MU, Murrah; ME, Mediterranean; MD, mixed-breed; Ho, observed heterozygosity; HE, expected heterozygosity; SI, Shannon index; FIS, inbreeding coefficient; HWP, Hardy-Weinberg probability. Frequencies are in parentheses. Source: Authors. 
Zetouni et al., (2013) observed genotypic frequencies of 0.30 for AA genotype, 0.54 for AG and 0.16 for GG in leptin gene of Murrah buffaloes. These frequencies are discrepant of our results, probably because we did not find GG genotype in our Murrah group. In addition, Pauciullo et al., (2010) evaluated a population of mediterranean buffaloes for SCD gene and found genotypic frequency of AA $(0,69), \mathrm{AC}(0,26)$ and $\mathrm{CC}(0,05)$. Our genotypic frequency for mediterranean buffaloes is different. However, when we compared to mixed-breed, the AA (0.69) and AC (0.31) frequency is similar to that reported by Pauciullo et al., (2010).

The heterozygosities observed and the expected were lower or equal than 0.50 in all of the groups studied and for two genes, excepted in the mixed-breed group for leptin gene. The Shannon index was lower than 1.00 in all of the groups and genes, and the FIS values indicated endogamy in the Murrah and mixed-breed groups. For Leptin and $S C D$, the $\mathrm{F}_{\mathrm{IS}}$ values no indicated endogamy for all groups. The Hardy-Weinberg equilibrium did not differ significantly $(\mathrm{P}>0.05)$ from the proportions expected in any of the breed groups in all genes.

Figure 1, presents the results for milk production. There were no significant associations between genotype and milk production in any of the breed groups studied $(\mathrm{P}>0.05)$.

Figure 1. Milk production performance $(\mathrm{kg})$ of each genotype within the breed groups.

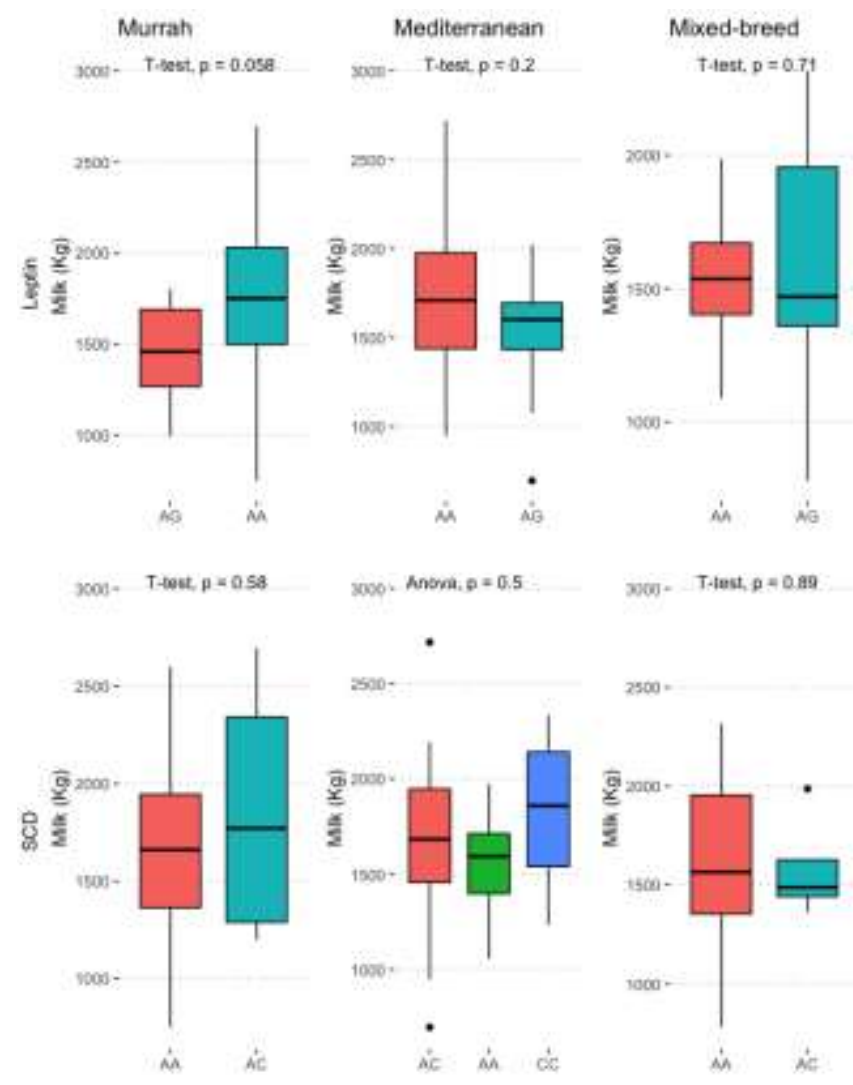

Source: Authors.

Nasr et al. (2016) demonstrated that Egyptian buffaloes with AA genotype produced more milk, fat \% and fat yields than animals with GG and AG genotypes. The same authors suggested that the A was the predominant allele and had a considerable consequence on rising milk yield. In the present study, the A allele is the most frequent in leptin gene for all breed groups. However, this allele not shows statistical significance association with milk production. Dubey et al., (2014) claim the 
infrequent allele is anticipated to be dispersed more in the form of heterozygotes than in homozygous state and it is improbable that the $\mathrm{G}$ allele will be totally eradicated from the population, except with targeted selection opposed to this allele. In our study, the GG genotype was not found in any of the breeds, which is expect since the GG genotype is associated with low milk production and our buffalo heard studied belongs to animal breeding program.

Pauciullo et al., (2012) studied SCD gene in mediterranean buffaloes and found an over-dominance effect of the genotype AC associated with milk yield Buffaloes compared with AA and CC. Gu et al., (2019) demonstrated that the A to C substitution generated a higher binding affinity of the Sp1 transcription factor to the gene promoter. The stronger Sp1 binding produced a quantitative difference in gene expression, albeit not directly linked to desaturation activity of $S C D$ in mammary gland. In our studies, we found the CC genotype only in the Mediterranean breed. Is necessary more studies with others population for demonstrated if this genotype can be used as an exclusive marker for the breed.

In the present study, the allele frequencies resulted in low genetic variability in Murrah, Mediterranean and mixedbreed, despite there being no deviation from the Hardy-Weinberg equilibrium. This low variability indicates that inbreeding has occurred.

\section{Conclusion}

In conclusion, the A allele was more representative in leptin and SCD genes in all breed groups. No significant effects between genotypes and milk production were found in the present study, but there is an indicative that AA genotype in leptin gene affects milk production in Murrah breed. Further studies with larger sample are necessary to prove this result.

\section{Acknowledgments}

We are grateful to the Brazilian Coordination for the Improvement of Higher Education Personnel (CAPES), the Federal University of Pará and Embrapa Eastern Amazon for all the support.

\section{References}

Araújo, K. B., Rangel, A. H., Fonseca, F. C., Aguiar, E. M., Simplício, A. A., Novaes, L. P., \& Júnior, D. M. L. (2012). Influence of the year and calving season on production, composition and mozzarella cheese yield of water buffalo in the State of Rio Grande do Norte, Brazil. Italian Journal of Animal Science, 11(1), e16.

Machado, E. B., Souza, B. B., Guimarães, R. C., Azevedo, J. S. N., Gonçalves, E. C., Ribeiro, H. F. L. \& ... Filho, E. S. (2016). Polymorphism in the melatonin receptor gene in buffalo populations of the Brazilian Amazon. Genetics and Molecular Research 15, 1-6.

Bartha, T., Sayed-Ahmed, A., \& Rudas, P. (2005). Expression of leptin and its receptors in various tissues of ruminants. Domestic animal endocrinology, 29(1), 193-202.

Bhattacharya, A., Banu, J., Rahman, M., Causey, J., \& Fernandes, G. (2006). Biological effects of conjugated linoleic acids in health and disease. The Journal of nutritional biochemistry, 17(12), 789-810.

Food and Agriculture Organization. (2003). World agriculture: towards 2015/2030: an FAO perspective. FAO.

Dubey, A., Kant, S., Agarwal, S., Dixit, S., Mahadi, A. A., \& Tiwari, S. (2014). A study on association of leptin receptor gene polymorphism with obstructive sleep apnea syndrome in overweight and obese north Indian subjects. Indian journal of physiology and pharmacology, 58(3), 222-228.

Feuermann, Y., Mabjeesh, S. J., \& Shamay, A. (2009). Mammary fat can adjust prolactin effect on mammary epithelial cells via leptin and estrogen. International journal of endocrinology, 2009, 1-8.

Gu, M., Cosenza, G., Iannaccone, M., Macciotta, N. P. P., Guo, Y., Di Stasio, L., \& Pauciullo, A. (2019). The single nucleotide polymorphism g. 133A> C in the stearoyl CoA desaturase gene (SCD) promoter affects gene expression and quali-quantitative properties of river buffalo milk. Journal of dairy science, $102(1), 442-451$

Hu, X., Juneja, S. C., Maihle, N. J., \& Cleary, M. P. (2002). Leptin-a growth factor in normal and malignant breast cells and for normal mammary gland development. Journal of the National Cancer Institute, 94(22), 1704-1711.

IBGE (Brazilian Institute of Geography and Statistics) (2016). Produção da pecuária municipal, Rio de Janeiro, 44: 1-51. 
Research, Society and Development, v. 10, n. 13, e233101321222, 2021

(CC BY 4.0) | ISSN 2525-3409 | DOI: http://dx.doi.org/10.33448/rsd-v10i13.21222

Kassambara, A., \& Kassambara, M. A. (2020). Package 'ggpubr'.

Kininis, M., \& Kraus, W. L. (2008). A global view of transcriptional regulation by nuclear receptors: gene expression, factor localization, and DNA sequence analysis. Nuclear receptor signaling, 6(1), nrs-06005.

Malpaux, B., Migaud, M., Tricoire, H., \& Chemineau, P. (2001). Biology of mammalian photoperiodism and the critical role of the pineal gland and melatonin. Journal of biological rhythms, 16(4), 336-347.

McWilliam, H., Li, W., Uludag, M., Squizzato, S., Park, Y. M., Buso, N. \& Lopez, R. (2013). Analysis tool web services from the EMBL-EBI. Nucleic acids research, 41(W1), W597-W600.

Naserkheil, M., Miraie-Ashtiani, S. R., Sadeghi, M., Nejati-Javaremi, A., Park, C. W., Min, K. S., \& Lee, D. (2019). Exploring novel single nucleotide polymorphisms and haplotypes of the diacylglycerol O-acyltransferase 1 (DGAT1) gene and their effects on protein structure in Iranian buffalo. Genes \& genomics, 41(11), 1265-1271.

Nasr, M. A. F., Awad, A., \& El Araby, I. E. (2016). Associations of leptin and pituitary-specific transcription factor genes' polymorphisms with reproduction and production traits in dairy buffalo. Reproduction in Domestic Animals, 51(4), 597-603.

Pauciullo, A., Cosenza, G., D’avino, A., Colimoro, L., Nicodemo, D., Coletta, A., ... \& Ramunno, L. (2010). Sequence analysis and genetic variability of stearoyl CoA desaturase (SCD) gene in the Italian Mediterranean river buffalo. Molecular and Cellular Probes, 24(6), 407-410.

Pauciullo, A., Cosenza, G., Steri, R., Coletta, A., La Battaglia, A., Di Berardino, D., ... \& Ramunno, L. (2012). A single nucleotide polymorphism in the promoter region of river buffalo stearoyl CoA desaturase gene (SCD) is associated with milk yield. Journal of dairy research, 79(4), 429-435.

Peakall, R. \& Smouse, P.E. (2012). GenAlEx 6.5: genetic analysis in Excel. Population genetic software for teaching and research--an update. Bioinformatics.; 28: $2537-2539$

Raymond, M. (1995). Population genetics software for exact test and ecumenicism. J Heredity, 86, 248-249.

Rosales, F.P, \& Batalha, M.O. (2013). Coordination of the chain of buffalo milk in São Paulo State (Brazil). Buffalo Bulletin.; 32 : $1200-1203$.

Safari, A., Hossein-Zadeh, N. G., Shadparvar, A. A., \& Arpanahi, R. A. (2018). A review on breeding and genetic strategies in Iranian buffaloes (Bubalus bubalis). Tropical animal health and production, 50(4), 707-714.

Sambrook, J., Fritsch, E. F., \& Maniatis, T. (1989). Molecular cloning: a laboratory manual (No. Ed. 2). Cold spring harbor laboratory press. 